\title{
The U.S. Military and American Commitment to Taiwan's Security
}

\begin{abstract}
This article focuses on how the U.S. military assesses the threat of a Taiwan Strait crisis over the next two decades, America's possible responses, and the U.S. capacity for effective intervention. It examines the drivers behind the U.S. approach, highlighting their implications.
\end{abstract}

KEYWORDS: China, Taiwan, Taiwan Strait, United States, U.S.-China relations

The government of the United States of America is committed under the Taiwan Relations Act (TRA) of 1979 to "maintain the capacity of the United States to resist any resort to force or other forms of coercion that would jeopardize the security, or the social or economic system, of the people on Taiwan." As a symbol of American commitment to the security of Taiwan, the Act is no less credible than the mutual defense treaties the U.S. has with its other major Asian allies, or the defense treaty with Taiwan, that it in effect replaced. The only threat to Taiwan's security and existence as a state comes from the People's Republic of China (PRC).

The passing of the Act was intended to reassure Taiwan (officially known as the Republic of China [ROC]) of American support when the U.S. ended formal diplomatic relations with it and opened them instead with China in I97I; the ROC until then had occupied China's seat at the

Steve Tsang is Professor of Contemporary Chinese Studies and Director of the China Policy Institute at the University of Nottingham, U.K. He is also an Emeritus Fellow of St Antony's College, Oxford University. He would like to thank Captain Jeff Davis, Senior Associate Member of St Antony's College and Visiting Fellow of the Program on the "Changing Character of War" at Oxford University, 2007-08, and currently Commander of Carrier Air Wing Eight, United States Navy, for his invaluable input in discussing and criticizing constructively the original draft. He is also grateful to the Nottingham Taiwan Studies Program for support. Email: <steve.tsang@nottingham.ac.uk>.

I. TRA, January I, 1979, <http://www.ait.org.tw/en/about_Ait/tra/>, accessed February I5, 2010.

Asian Survey, Vol. 52, Number 4, pp. 777-797. ISSN oo04-4687, electronic ISSN I533-838X. (C) 2012 by the Regents of the University of California. All rights reserved. Please direct all requests for permission to photocopy or reproduce article content through the University of California Press's Rights and Permissions website, http://www.ucpressjournals.com/reprintInfo.asp. DOI: AS.20I2.52.4.777. 
U.N. ${ }^{2}$ The Act was meant to deter the PRC from seeking a non-peaceful means to change the status of Taiwan. It does not legally commit the U.S. to come to Taiwan's defense automatically. Nor does it require the U.S. administration of the day to go beyond upholding American national interests in case a crisis over Taiwan were to escalate into a full scale, potentially nuclear, war with the PRC. It merely requires the administration of the day to start a "process by which the United States may recognize and act upon its own security interests." ${ }^{3}$ This is not fundamentally different from the stipulation in the Mutual Defense Treaty with the ROC (1955) that required the U.S. government to "act to meet the common danger in accordance with its constitutional processes." What the TRA does stipulate is that "any effort to determine the future of Taiwan by other than peaceful means, including by boycotts or embargoes, [is] a threat to the peace and security of the Western Pacific area and of grave concern to the United States." 5

To meet the requirement that the U.S. must maintain the capacity to resist changes being forced upon Taiwan, the U.S. Pacific Command (PA$\mathrm{COM}$ ) has a contingency plan to help Taiwan defend itself. This started as a concept plan (CONPLAN 5077) under the Reagan administration and was upgraded to an operation plan (OPLAN-5077-4) during the first term of the George W. Bush administration. The upgrading means that units likely to be required are being nominally assigned. ${ }^{6}$ The need to meet such a contingency is consequently taken more into account by U.S. planners as forces are regularly modernized, restructured, or redeployed. Because there are only a handful of OPLANs in existence, the upgrade reflects how seriously the U.S. takes the matter-even after the "global war on terrorism" became the focus of U.S. planners following the September II attacks. However, making a contingency plan and upgrading it does not imply that the U.S. is actively

2. Richard C. Bush, At Cross Purposes: U.S.-Taiwan Relations since 1942 (Armonk, N. Y.: M. E. Sharpe, 2004), pp. 150-55.

3. Richard M. Pious, "The Taiwan Relations Act: The Constitutional and Legal Context," in Louis W. Koenig, James C. Hsiung, and King-yuh Chang (eds.), Congress, the Presidency, and the Taiwan Relations Act (N.Y.: Praeger, 1985), p. I6I.

4. The Mutual Defense Treaty between the U.S. and the ROC (1955), <http://www.taiwandocuments.org/mutualor.htm>, accessed February 24, 2012.

5. “Taiwan Relations Act," January I, I979, <http://www.ait.org.tw/en/about_Ait/tra/>, accessed February 15, 2010.

6. William M. Arkin, "America's New China War Plan," June 10, 2006, <http://militarynuts. com/ar/t9II.htm>, accessed February 27, 2012. 
preparing, even less wishing, for a war with China. On the contrary, it is part of the deterrence.

In the event of a crisis over Taiwan, how the administration of the day will honor U.S. commitments to Taiwan will depend on a wide range of variables, in addition to the legal commitment, which is a non-variable factor. ${ }^{7}$ The most important of these variables are the views of the president and his close advisers, Congressional opinions, and the relationship between the U.S. executive and the legislative branches at the time. They are in turn affected by the mood of the nation; political, economic, and budgetary priorities within the U.S.; the state of its worldwide commitments; the state of U.S.-China relations; the state of U.S.-Taiwan relations; how the crisis emerged; Taiwan's own capacity and determination to defend itself; and the general situation in East Asia, as well as the willingness of American allies to help. Since the time frame and the conditions under which such a crisis may arise cannot be predicted, this paper will not address these issues.

Instead, this paper focuses on how the U.S. military assesses the likely threat and requirements for it to respond over the next two decades, and its capacity to do so effectively. In an important sense, the U.S. responses will vary according to specific scenarios. It is impossible to examine all the scenarios by which the PRC could use force against Taiwan: the range is limited only by the imagination of the planners. An apparently obvious one is a full scale amphibious assault similar to the Normandy landings of 1944. This can be dismissed as the most unlikely choice, since despite its impressive building program for amphibious ships, "the total number of troops and equipment that China would be able to transport for force projection remains constrained." ${ }^{\text {T }}$ To mount a Normandy-style attack would also require a command of the sea and air that Chinese forces cannot achieve within the next two decades if U.S. forces should actively support Taiwan. This assessment also reflects a basic working premise of this paper—unless it feels "provoked" by Taiwan, the PRC will not take the initiative to use force if it believes it cannot win or effectively deter the U.S. from helping Taiwan to defend itself. This, in turn, is based on the political reality that the legitimacy of the PRC

7. How the terms of the TRA should be implemented is a variable factor that will be affected by the other factors. The legal commitment is not a variable, until the Act is repealed or amended.

8. Taylor Fravel, "China's Search for Military Power," Washington Quarterly 31:3 (2008), p. I34. For a study of the most likely war scenarios, see Andrew Nien-Dzu Yang, "The Alternative to Peace: War Scenarios," in Steve Tsang, ed., Peace and Security across the Taiwan Strait (Basingstoke, U.K.: Palgrave Macmillan, 2004), pp. I68-88. 
leadership could be greatly jeopardized if it adopted an adventurist policy over such a highly nationalistically charged issue and ended up in a humiliating retreat. Hence, this article will focus on the most likely scenario, which could also transform itself into the worst case one.

The scenario most preferred by the PRC leadership is one of successfully persuading Taiwan to start negotiations for unification by an implied threat to use force. Should this materialize as planned, it would be Beijing's (but not the U.S.'s or Taiwan's) best case scenario. However, this approach could easily transform itself into a completely different one-the most likely scenario-as a result of miscalculation followed by unwitting escalation. In specific terms, the most likely scenario involves the PRC authorities miscalculating that they can effectively deter the U.S. from interfering as they demonstrate overwhelming military superiority to intimidate Taipei, requiring it to open formal negotiations for unification. As will be examined below, should democratic Taiwan offer resistance stronger than Beijing expects while the U.S. refuses to be deterred, escalation would become unavoidable. The PRC leadership fears it would lose legitimacy, should it then back down from fulfilling its "sacred mission" to unify Taiwan. The direction of escalation for any crisis is not pre-determined. But the widespread belief among many Chinese officers is that "killing a carrier"-either by sinking or damaging the ship so badly that it can no longer operate-is the most effective way to persuade the U.S. to back off; this means it may well be adopted as policy. Should this trigger the U.S. to respond with greater determination and force (examined below), we will see an escalation spiral, which could easily turn into the worst case scenario.

Neither the U.S. nor the PRC wishes the worst case scenario to materialize, because it would involve a military confrontation. In the event of a crisis, both sides will try to contain and avoid escalation to a full scale war between two major nuclear powers. But avoiding escalation after casualties have occurred and national prestige has been put at risk will require extraordinary authority, good sense, confidence, and effective diplomacy to reach a political settlement that leaves leaders of both countries with the capacity to face down their domestic political enemies.

The risk that the PRC may take actions over Taiwan that subject Beijing and Washington to a possible spiral of escalation is not negligible. This is because there is considerable scope for Chinese analysts and policy makers to think that the U.S. can be deterred from fulfilling the terms of the TRA, 
particularly given the relative rise in Chinese capabilities and the expected reshaping and redefining of U.S. ones over the next two decades. ${ }^{9}$

Hence, this article examines and explains the dynamics that drive the U.S. military responses to the most probable scenario. The raison d'être for the paper is to reduce the scope for policy makers and analysts, particularly in China, to miscalculate how the U.S. would respond to a Taiwan Strait crisis. ${ }^{10}$ If miscalculation can be eliminated, this should deter the PRC from taking initiatives that could spawn an escalation spiral.

In the event of a crisis, it is up to the U.S. government and Congress to make a policy response proportionate to national interest, but it is the responsibility of the Department of Defense (DOD) to give the national command authority the needed recommendations and capacity to fulfil the terms of the TRA. Understanding the U.S. military's basic thinking on the problem, and its ability to respond to a Taiwan-related security threat, should help policy makers avoid a miscalculation that might escalate from a calculated and limited use of force into a major confrontation no one desires. A separate but related working premise for this paper is that whatever very long term ambition the Chinese government may have, its objectives over Taiwan remain as they have publicly maintained since I950, rather than an excuse to launch a full scale war with the U.S.

The main thrust of this paper is to examine how the U.S. military will meet the kind of threat in the most likely scenario of the PRC government using force to make Taiwan accept unification with the Mainland. The paper outlines briefly the perceived threats and focuses on how the U.S. military establishment will assess and respond to them. In so doing, it addresses the question of how effectively Beijing can deter the U.S. from fulfilling the terms of the TRA. The paper ends with an evaluation of the implications of the findings and suggests that counterintuitive though it may be, it is in the PRC's interest that Taiwan should be allowed to maintain a credible defense capability in the foreseeable future.

9. Guangqian Peng, "Peace or War: Taiwan at a Critical Juncture," China Security 4:I (2008), pp. 67-68; and Chito Romana, "Does China Want to Be Top Superpower?" ABC News, March 2, 20IO, <http://abcnews.go.com/International/china-replace-us-top-superpower/story?id=9986355>, accessed March 3, 2010.

Io. Chinese officers who are allowed to articulate their views often reveal a poor understanding or a somewhat dismissive assessment of the U.S. commitment to respond to a Taiwan crisis. David Shambaugh, Modernizing China's Military: Progress, Problems, and Prospects (Berkeley: University of California Press, 2002), pp. 309-II. 


\section{THREAT ANALYSIS AND MISSION REQUIREMENTS}

The Chinese government prefers to persuade or passively coerce Taiwan to join China without fighting a war, but it has never given up the right to use force to achieve this objective, which the Chinese Communist Party (CCP) sees as a matter of national sovereignty and territorial integrity-a core interest. ${ }^{11}$ In light of Taiwan's strategic location from the Chinese perspective, the Chinese government also deems control over Taiwan to be a "vital national interest without which the security and welfare of the Chinese state will be in jeopardy." ${ }^{2}$

After independence-minded Taiwanese President Chen Shui-bian of the Democratic Progressive Party left office in 2008, the Chinese government adjusted its policy, easing tension. ${ }^{13}$ Its current policy is to get Taiwan as fully integrated as possible economically, socially, and culturally with mainland China so that Taiwan will find it too costly to resist a future call for unification, backed by an implied use of force. The calculation is that when China demands unification it can demonstrate such overwhelming comprehensive national strength that the government of Taiwan will have no choice but to agree to negotiate the terms for unification. To make such a prospect acceptable to Taiwan, Beijing is prepared to exercise maximum flexibility, including negotiating the political framework for unification.

The problem is that however spectacularly China has progressed in the past three decades, including impressive improvement in governance, its "consultative Leninist" political system does not practice democracy or respect human rights. ${ }^{14}$ The CCP leadership does not understand how proud and attached the people of Taiwan are to their democracy and way of life. If they were forced to choose, they could not be expected to accept unification under a Leninist regime, albeit a consultative one that is delivering impressive economic growth. The maximum degree of flexibility that Beijing is willing to exercise is limited ultimately by a rigid framework: unification under the

II. Dai Bingguo, "Zhongguo de hexin liyi shi shenme?” [What are China's core interests?], China Election and Governance website of the Carter Center, July 29, 2009, <http://www.chinaelections. org/newsinfo.asp?newsid=154270>, accessed February 17, 2010.

I2. Alan M. Wachman, Why Taiwan? Geostrategic Rationales for China's Territorial Integrity (Stanford: Stanford University Press, 2007), p. I6I.

13. Xin Qiang, "Mainland China’s Taiwan Policy Adjustments," China Security 5:I (2009), pp. 53-64.

14. Steve Tsang, "Consultative Leninism: China's New Political Framework," Journal of Contemporary China 18:62 (2009), pp. 865-80. 
continued monopoly of power by the CCP. ${ }^{15}$ This framework provides no scope for democracy to continue in Taiwan. With Taiwan's defense forces now fully nationalized and answerable to a democratically elected government, they can be expected to fight to defend their own freedom, democratic way of life, individual dignity, and families. Hence, the Chinese calculation is unlikely to work through peaceful assimilation. As such, a Chinese attempt to use implied force to require Taiwan to negotiate for unification will almost certainly be rebuffed.

While there is no consensus in Taiwan over what is the best option for its future, a clear majority rejects unification, and this trend is strengthening. ${ }^{16}$ This implies that no state presidents in Taiwan, regardless of party affiliation or personal disposition, can gain reelection if they should seek unification with China. With the CCP's own legitimacy dependent on its capacity to deliver on this nationalistic aspiration, events could easily escalate because increasingly powerful nationalist elements will probably force the hands of the leadership as a whole. ${ }^{17}$ The impact of nationalism on the interpretation of China's policy to rise peacefully, which is a key driver behind its Taiwan policy, can be seen in Beijing's informal elevation of the South China Sea to become a "core national interest" in the spring of 20I0. ${ }^{18}$ In so doing, the Chinese leadership did not jettison the policy to rise peacefully but merely took a more nationalistic interpretation.

This nationalistic articulation of the "peaceful rise strategy" is highly counterproductive because it causes alarm among neighbors and raises questions about China's assertion that its rise threatens no one. ${ }^{19}$ But it was introduced nevertheless. In other words, a Chinese initiative to coerce the government in

15. The concept of maximum flexibility within a rigid framework was first used by Steve Tsang to explain how the PRC government handled the reunification of Hong Kong with mother China. See "Maximum Flexibility, Rigid Framework: China's Policy towards Hong Kong and Its Implications," Journal of International Affairs 49:2 (Fall 1996), pp. 4I3-33.

16. Chia-lung Lin, "The Importance of China and Identity Politics in Taiwan's Diplomacy," in Steve Tsang, ed., Taiwan and the International Community (Oxford, U.K.: Peter Lang, 2008), pp. $58-59$.

17. Cong Riyun, "Nationalism and Democratization in Contemporary China," Journal of Contemporary China 18:62 (2009), p. 847.

18. John Pomfret, "Beijing Claims 'Indisputable Sovereignty' over South China Sea," Washington Post, July 3I, 20IO, <http://www.washingtonpost.com/wp-dyn/content/article/2010/07/30/ AR2010073005664.htm>, accessed August 2, 2010.

19. Donald K. Emmerson, "China's 'Frown Diplomacy' in Southeast Asia," PacNet 45, October 6, 2010 (Honolulu: Pacific Forum CSIS [Center for Strategic and International Studies]), <http:// csis.org/files/publication/pacio45.pdf>, accessed November 22, 2010. 
Taiwan to open negotiations for unification can easily escalate into a political necessity to use force if the government in Taipei acts on the domestic political imperative and rejects the call for unification. Whether Beijing will take the initiative to require Taipei to accept unification depends ultimately on China's assessment of its capacity to deter the U.S. from fulfilling the terms of the TRA. ${ }^{20}$ Beijing will act if it believes it can do so.

How to respond as a state to such an eventuality is a matter for politicians in Washington, not one for the military. The assessment of overall U.S. national interest requires a political judgement that is beyond the remit of the defense establishment. For the DOD, its responsibilities in this regard are to support U.S. interests, policy, and strategy, as well as maintain a global presence to influence, deter, and provide for regional stability. To do so, the department recognizes an implicit duty under the TRA to be prepared for a contingency across the Taiwan Strait. The critical issues are what kinds of threat Taiwan would face and how U.S. forces could meet them effectively.

The most likely scenario of China actually using force will involve a clever combination of two basic requirements. ${ }^{21}$ On the one hand, it will mean precision strikes that aim to destroy Taiwan's command and control system, decapitate its political and military leadership, and destroy key military installations. ${ }^{22}$ This will require the application of information warfare, the use of short-range ballistic and cruise missiles, other precision guided weapons, and Special Forces to destroy key military installations, terrify the civilian population, and force the government in Taipei into submission before the U.S. political establishment can agree on how to respond. This is likely to be backed up by the mobilization and forward deployment of the field armies and amphibious units of the People's Liberation Army (PLA). On the other hand, the PLA will need to deter U.S. forces from coming to the active defense of Taiwan. This will involve the PLA attempting to seize control in the air, sea, and space domains and thus require Taiwan to accept or negotiate

20. Chinese opinion shapers with close links to policy makers habitually see the U.S. commitment to Taiwan's security as the key obstacle to unification, implying that if the former is removed, the latter can be achieved. See Guangjian Peng, "Peace or War: Taiwan at a Critical Juncture," China Security 4:I (Winter 2008), pp. 6I-69; and Xuetong Yan, "The Rise of China and Its Power Status," Chinese Journal of International Politics I:I (Summer 2006), pp. 27-29.

2I. Steve Tsang, "Drivers Behind the Use of Force," in idem, ed., If China Attacks Taiwan: Military Strategy, Politics, and Economics (London: Routledge, 2006), pp. 6-8.

22. Liu Qingyuan, Jiexi Zhonggong Guojia Anquan Zhanlue [Explaining the national security strategy of the Chinese communists] (Taipei: Yangzhi wenhua, 2003), pp. 132-37. 
for unification. If Taiwan's government follows suit, this would seriously undermine the legitimacy and international support for the U.S. to interfere.

If such a scenario should develop, any able commander of PACOM will quietly take certain basic precautionary measures in response, without prejudicing the outcome of the political process in Washington. OPLAN 5077-4 (or its revised edition) will be activated and updated to meet the requirements of the day and will be given precedence over other routine deployments. Forces will be put in place to answer a call to duty by the political masters within a week or so. Commanders will put forces on alert, deploy the capital ships to sea to reduce their vulnerability, and order U.S. bases in East Asia and the Pacific to get ready to receive, service, and support additional combat units that may be redeployed from mainland U.S. bases. At the wider national level, forces will be put on a higher state of readiness so that carrier air-wings, plus air force and other units outside of PACOM, can be ordered quickly to the Pacific. There, they will join carriers, other platforms, and bases for forward deployment, should the president and Congress decide to support Taiwan in its defense.

The basic assumption of the U.S. military is the following: should it find itself facing the prospect of a confrontation with a great power that is increasingly becoming a "near peer competitor," it will make all combat ready units available as quickly as possible. It will not respond only with forces normally available within PACOM. Given that by December 2012 all Io active service U.S. carriers share the same basic platform, design, training, and readiness construct, the transfer and redeployment of carrier air-wings from wherever they may be to the Pacific Ocean in an emergency is a relatively straightforward matter. ${ }^{23}$ At present, even the carrier deployed in support of U.S. operations in Afghanistan can be redeployed. The U.S. Air Force (USAF) maintains sufficient capability and is globally postured to quickly backfill naval air assets if required. Additionally, and if necessary, a less combat ready carrier air-wing from the U.S. can be reconstituted and mobilized for deployment even if its assigned carrier cannot be because of the large maintenance requirements of refitting. Despite the pressure on resources and extensive deployments since the early 2000s, at a push the U.S. Navy can surge six

23. Until the end of 20I2, there are II carriers. There will only be Io after the USS Enterprise, the only non-Nimitz class ship still in service, is decommissioned in December. The coming into service in the next decade of the Gerald Ford class of super carriers should not complicate matters too much, as they can accommodate everything a Nimitz class carrier-based air-wing requires. 
carrier strike groups in short order to a contingency, with an additional two strike groups as backup. ${ }^{24}$ Surface combatant ships not required for carrier protection will be put on a state of readiness for deployment to major sea routes, so that the option will be available to the U.S. government to secure sea lines of communication. The "tyranny of distance" for the deployment of U.S. forces outside of PACOM cannot be eliminated, but its impact can and almost certainly will be reduced by the early informal mobilization of forces while politicians deliberate in Washington.

In assessing the actual requirements, the U.S. military will need to judge the level and nature of threats from the PLA and the capacity of Taiwan's defense forces to hold off the PLA while the political process runs its course in Washington. Until the U.S. government has decided on its policy, the military will merely observe, assess, prepare, and pre-position to harmonize national strategy with routine forward presence to influence and reassure allies.

Assessing the scale and nature of assistance that Taiwan needs is a significant factor that policy makers in Washington will take into account as they deliberate a policy. The less Taiwan needs direct U.S. assistance, which implies a higher degree of readiness on the island to respond to a military contingency, the easier it is for such support to be given. If, for example, Taiwan requires the U.S. to supply missiles and other munitions or even weapon systems to replace battle losses, these can be provided relatively easily and quickly within the constraints of inventory. In the event of a need to replace battle losses among Taiwan's F-I6s, this can be done by diverting such aircraft from the USAF or Air National Guard. ${ }^{25}$ The scope for this process is receding by the year, however. The USAF stopped purchasing F-I6s in 2007, and the bulk of them are reaching their 6,0oo-hour life expectancy, although several programs are in place to extend life to 8,000-IO,ooo hours. Thus, the ability for the U.S. to replace Taiwan losses quickly will decline, and a decade from now there will be gaps in how quickly reinforcement and replacement may be accomplished. ${ }^{26}$ One possible step up the ladder of military intervention would be helping Taiwan to break a PLA blockade or taking over the

24. Henry L. Dickson, "Surging Ahead, Navy Implements New Fleet Response Plan," All Hands Magazine, November 2003, via <http://findarticles.com/p/articles/mi_moIBQ/is_IO39/ ai_III463944/>.

25. Something similar happened before: The USAF dispatched active-service jets to the Israeli Air Force to replace battle losses during the Yom Kippur War of 1973.

26. For detailed analysis, see "F-I6 Fighting Falcon Service Life," undated, at <www.globalsecurity.org/military/systems/aircraft/f-I6-life.htm>, accessed August 2, 20 IO. 
maritime and air security east of Taiwan in order to free up Taiwanese forces to defend their western coast and the Strait. Unless U.S. forces tasked with such missions were specifically targeted by the PLA—which would seriously risk escalation—such missions could be accomplished by U.S. forces operating out of nearby bases and naval platforms and would likely be approved by Washington relatively readily.

The implications of the shift in the balance of military power across the Taiwan Strait in China's favor, which is already happening, are not as straightforward as it may appear to Chinese military planners. Indeed, a significant further strengthening of the PLA's advantages needs to materialize before the CCP leadership can take the initiative, without "provocation" from Taiwan, to require the island to accept unification. While such a demonstration of the PLA's overwhelming advantages may intimidate many people in Taiwan and persuade some U.S. opinion leaders to advocate caution, it would also likely trigger the U.S. military to prepare to interfere more quickly and more extensively.

The last time U.S. forces actively supported Taiwan's defense was during the crisis of 1958 . On this occasion, the crisis was so severe that President Dwight Eisenhower considered using nuclear weapons if absolutely necessary. While the U.S. "massively reinforced" Taiwan, no U.S. combat support was actually required because the Taiwanese, particularly the air force, performed spectacularly. ${ }^{28}$ With Taiwan's defense capacity currently in relative decline, ${ }^{29}$ Taipei is unlikely to repeat the sterling performance of 1958 in a future crisis. This means that if Chinese deterrence against the U.S. should fail, the need for U.S. forces to intervene could arise quickly. Intervention might include attacking PLA missile batteries and command and control centers, as well as logistics, communication, and staging bases opposite Taiwan, although the risk of escalation means that such attacks will not be launched without presidential authorization. Taiwan is aware of this and is trying to

27. Morton H. Halperin, The 1958 Taiwan Strait Crisis: A Documented History (Santa Monica, Calif.: RAND, 1966), p. 99. The 1996 U.S. deployment of two carrier battle groups was primarily for moral support and to send a clear message to Beijing. They were not required or expected to give active support to Taiwan's defense forces.

28. Steve Tsang, The Cold War's Odd Couple: The Unintended Partnership between the Republic of China and the United Kingdom, 1950-1958 (London: I. B. Tauris, 2006), pp. I46-47.

29. Peter Enav, "Pentagon Paints Grim Picture of Taiwan Air Defense," Washington Post, February 22, 20I0, <http://www.washingtonpost.com/wp-dyn/content/article/2010/02/22/AR2010022201350. html>, accessed February 23, 2010. 
minimize such a need by developing and deploying surface to surface missiles for such a contingency. But this does not change the reality that the higher the level of direct U.S. military involvement, the greater the risk of unintended escalation.

In general terms, the more seriously a threat is perceived by the U.S. military, the more resources are devoted to meet it. U.S. military doctrine since World War Two has instilled in its officers a sense that the services will, when the situation demands, meet whatever challenges they face with the resources they have at hand. But U.S. commanders also expect to support and protect their forwardly deployed forces generously; the idea that generals win battles but logistics win wars has long been part of this doctrine. The U.S. military's steadily growing appreciation of the PLA's impressive improvements in capabilities in the past two decades means that the U.S. military will take the prospect of having the PLA as an adversary most seriously. It will deploy everything at its disposal that is not irretrievably tied down in ongoing operations to face such an eventuality. This implies that even weapon systems based in the continental U.S., such as the missile defense system in Alaska, will be activated to support and protect forwardly deployed units.

Given current U.S. military budgetary allocation and the reconfiguration of its forces, helping Taiwan defend itself will place a huge and increasing strain on American global capabilities. Before he left office, former Defense Secretary Robert Gates had signaled significant and lasting budget cuts designed to trim 30\% each from systems, weapons, and platform procurement. The cuts were upheld by his successor, Leon Panetta. They include modification of aircraft carrier procurement lines, which will result in fewer carriers being available as well as near-term elimination of a carrier air-wing. This will have a significant impact on deployment, redeployment, and backfilling of forces from one contingency to another. In other words, the process will reduce U.S. capacity to "surge" naval and air power in the event of a crisis over Taiwan. Indeed, the U.S. Navy, a key player in any operation to support Taiwan, has already made most of the efficiency gains that can be achieved without reducing operational capacity. It has managed a stable deployment of fleet and ships despite a $20 \%$ decrease in total battle force size over the past decade. ${ }^{30}$ But this process cannot be sustained indefinitely. The number

30. Daniel Whiteneck, Michael Price, Neil Jenkins, and Peter Swartz, The Navy at a Tipping Point: Maritime Dominance at Stake? (Alexandria, Va.: Center for Naval Analysis and Solutions Study, 20Io), p. 5. 
of ships training and conducting exercises in mainland U.S. decreased from around 70 in 1998 to 20 in 2010 . This means the Navy's capability will decline over time. It also means that on the current trajectory, the Navy's flexibility to meet its global responsibilities, including Taiwan, will be affected adversely as the decade progresses.

\section{CAN CHINA DETER THE U.S. MILITARY?}

How important are the expected decline in U.S. capabilities and the improvements in China's, including the muscle to deny U.S. forces access to the Taiwan region? Will they tip the balance and deter the U.S. from helping Taiwan in a crisis? The PLA has made remarkable progress in developing area denial capabilities in the past Io years. These include the deployment of modern ship-based, anti-ship cruise missiles such as the Sunburn (SS-N-22) and Sizzler (SS-N-27) systems imported from Russia. Indeed, this progress also derives from improvements in officer training, decision making, and delegation of decision making to combat units. Nonetheless, it is the deployment of powerful new weapon systems that most catches the public imagination.

The first and foremost of the long-standing key assets for area denial in the inventory of the PLA Navy remains its modernizing fleet of 59 attack submarines, to which new boats are still being added. The submarines have increasingly posed a grave potential threat to the safety of U.S. carrier strike groups. Since 1995 the Chinese submarine fleet has been upgraded by 28 modern vessels, including I2 Russian-made Kilo-class boats. ${ }^{31}$ The quality and capabilities of the more recent indigenous submarines, such as the Song- and Yuan-class boats, have also improved dramatically. ${ }^{32}$ Indeed, a Song submarine surfaced within five miles of the USS Kitty Hawk, inside its screen of escorts, in October 2006. ${ }^{33}$ This put the carrier within range of anti-ship missiles and torpedoes. However, whether Chinese submarines can breach the three-dimensional anti-submarine surveillance of a fully alert carrier strike

3I. See Ronald O'Rourke, "China Naval Modernization: Implications for U.S. Navy Capabilities-Background and Issues for Congress," CRS [Congressional Research Service] Report for Congress, RL33153, October I8, 2007.

32. Office of Naval Intelligence, The People's Liberation Army Navy: A Modern Navy with Chinese Characteristics (Suitland, Md.: Office of Naval Intelligence, 2009), p. 2I.

33. Mackenzie Eaglen and Jon Rodeback, "Submarine Arms Race in the Pacific: The Chinese Challenge to U.S. Undersea Supremacy," February 2, 20Io, Heritage Foundation, <http://www. heritage.org/Research/NationalSecurity/bg2367.cfm>, accessed February 25, 2010. 
group in combat conditions remains uncertain. ${ }^{34}$ In any event, the increasing threat from the improving Chinese submarines is one that the U.S. Navy has regularly taken into account in its planning. Thus, at this point the growing potential threat still cannot deliver the deterrence that the PLA High Command may wish to achieve.

The most significant capability enhancement in area denial that the Chinese have been developing is a new anti-ship ballistic missile (ASBM) system based on the DF-2ID or CSS-5 land-based mobile missile, with a range of over I,500 km. ${ }^{35}$ It is equipped with maneuverable re-entry vehicles (MaRVs) capable of hitting moving ships at sea and has reportedly reached the testing stage. ${ }^{36}$ No other state has developed such a capability. If it proves effective, it will be extremely difficult to defend carriers within its range. The deployment of such a weapon system may require the U.S. to devote significant resources to counter it. However, the efficacy of an operational ASBM system in deterrence remains doubtful. The vulnerability of carrier battle groups may lead Washington to "pre-emptively destroy or disable missiles or supporting assets" such as the satellites that guide the missiles, instead. ${ }^{37}$

It is unlikely that the PLA will succeed in deterring the U.S. through this new weapon system. For example, firing a missile that deliberately misses hitting a carrier battle group will probably escalate, not deter. More likely, U.S. forces will attack and eliminate such a threat, whether it scores or not. Even though an operational Chinese ASBM capability will be taken very seriously, the U.S. Navy has never shied from putting its capital ships in harm's way if necessary. Furthermore, alternative platforms such as unmanned aerial vehicles can be deployed to perform some of the functions now commonly carried out by carrier-based strike aircraft, should the deployment of carriers become restricted.

In any event, how effective the Chinese ASBM system will be in knocking a carrier out of action remains to be seen. Should the U.S. Navy find itself fighting a war with the PLA, the prospect that America could lose a carrier or more has been taken into account, similarly with the possibility of a major battle with the Soviet Navy during the Cold War. Any idea that China, by

34. Michael Kuzik, "To Kill a Carrier," Stratfor, <www.stratfor.com>, July 2, 2008, p. 3.

35. Andrew S. Erickson and David D. Yang, "Using the Land to Control the Sea: Chinese Analysts Consider the Antiship Ballistic Missile," Naval War College Review 62:4 (Autumn 2009), p. 34.

36. Ronald O'Rourke, China Naval Modernization: Implications for U.S. Navy CapabilitiesBackground and Issues for Congress (Washington, D.C.: CRS, 2010), pp. 7-8.

37. Andrew S. Erickson, "Ballistic Trajectory: China Appears to Be Approaching Operational Capability with Its Anti-Ship Ballistic Missile Programme," Janés Intelligence Review (February 20Io), p. 3. 
crippling a carrier or demonstrating that it can, will deter the U.S. armed forces from fulfilling orders to go to Taiwan's defense is based on a misreading of the ethos of the U.S. military establishment.

On the contrary, if a U.S. carrier should become a "mission kill" or be rendered operationally ineffective (even if not sunk), this would have a huge psychological, perhaps galvanizing, impact on the Americans. The U.S. Navy has not suffered such a loss since the end of World War Two. Such a blow, particularly if it resulted from a stealthy, preemptive strike, is likely to have a "Pearl Harbor" or "September II" effect on U.S. forces, spurring them to fight back. The assumption that they would withdraw, as after the 1993 "Black Hawk Down"38 incident in Somalia, defies U.S. military tradition. Whether the general public, and in particular the political establishment, in the U.S. will react in line with the military establishment in a crisis over Taiwan will depend on the political reality at the time and cannot be predicted. But in a real crisis, "rally round the flag," persevere, and expect to win in the end have long been part of the American ethos and national experience; these are likely to be the default reaction.

The building up of China's capacity to deter the U.S. from sending forces to help Taiwan defend itself is also based on China's development of high technology capacity for a war of the future. This includes the testing of antisatellite missiles, ballistic missile defense capability, and cyber attacks. Since 1997, the Chinese military has adopted the principle laid down by then top leader Jiang Zemin that "informationized" warfare (xinxizhan) should become the core of China's new strategic thinking. ${ }^{39}$ This has now become part of the PLA's doctrine, known as "fighting local wars under informationized conditions," which "seeks to develop a fully networked architecture capable of coordinating military operations on land, in air, at sea, in space, and across the electromagnetic spectrum." ${ }^{40}$ This involves giving the PLA the capacity to

38. See Mark Bowden, Black Hawk Down: A Story of Modern War (New York: Atlantic Monthly Press, 1999). In 1993 the Clinton administration, propelled by the killing of I8 American soldiers in the battle of Mogadishu, pulled U.S. forces out of Somalia, citing the futility of a "poorly organized United Nations nation building operation." See Richard W. Stewart, "The United States Army in Somalia, I992-1994," <http://www.history.army.mil/brochures/Somalia/Somalia.htm>, p. 26, accessed February 25, 2010.

39. Zhang Mingrui, Zhonggong Guofang Zhanlue Fazhan [Developments in the national defense strategy of the Chinese communists] (Taipei: Hongye wenhua, 1998), pp. 484-86.

40. Bryan Krekel, Capability of the People's Republic of China to Conduct Cyber Warfare and Computer Network Exploitation (McLean, Va.: Northrop Grumman for the U.S.-China Economic and Security Review Commission, 2009), p. Io. 
use information network technology to connect its previously separate warfighting services and technologically advanced support units, including cyber warfare units, into an integrated force for operational purposes. Since then, finding "ways to catch up and leapfrog [the U.S.] has become a central tenet in this search for a new development model." ${ }^{41}$ Indeed, "PLA strategists firmly subscribe to the arguments ... that latecomers have important advantages over pioneers and that a highly selective approach is required to target only the most technologically advanced areas for development." ${ }^{42}$

It was in line with this new strategic thinking that China tested its antisatellite capability in January 2007. Because even a "small scale antisatellite attack in a crisis against 50 U.S. satellites . . could have a catastrophic effect not only on U.S. military forces, but on the U.S. civilian economy," this was meant to be a significant addition to the PLA's capacity to deter the U.S. military from interfering over Taiwan. ${ }^{43}$ The demonstration of this new capability was further augmented. In January 20I0, the Chinese tested "ground-based midcourse missile interception technology" by shooting down a ballistic missile in mid-flight. This was described by Professor Tan Kaijia of the Chinese National Defense University as a shield to defend China's own vital installations and thus an instrument to close an important window of vulnerability. ${ }^{44}$ Combined with the anti-satellite capability, this was meant to be, at least in part, a "demonstration of Chinese capability to disrupt and degrade U.S. space capabilities in the event of a Taiwan Strait conflict." ${ }^{35}$

Such deterrence is reinforced by the prospect that the U.S. may not enjoy as much advantage in cyber warfare against China as it does in conventional warfare. Indeed, the congressionally directed Independent Assessment Panel known as the Allard Commission takes the view that "without significant improvements in the leadership and management of national security space programs, U.S. space preeminence will erode 'to the extent that space ceases

41. Tai-ming Cheung, Fortifying China: The Struggle to Build a Modern Defense Economy (Ithaca, N.Y.: Cornell University Press, 2009), p. 243.

42. Ibid.

43. Michael P. Pillsbury, An Assessment of China's Anti-Satellite and Space Warfare Programmes, Policies, and Doctrines (paper submitted to the U.S.-China Economic and Security Review Commission, January 19, 2007), pp. 3, 17.

44. Peter J. Brown, "China Vents Anger with Missile Test," Asia Times Online, January 20, 2010, $<$ http://www.atimes.com/atimes/China/LA2oAdor.html>, accessed March I, 2010.

45. Ibid. 
to provide a competitive national security advantage." "'46 Notwithstanding doubts over whether the U.S. can sustain its current apparently declining advantages, no full-scale cyber war between major powers has ever been waged. ${ }^{47}$ Whether the technological edge the U.S. may now enjoy could be neutralized by the sheer volume and variety of cyber attacks from China in a crisis cannot be predicted.

As one analysis puts it, in the event of a "conflict with the U.S., China will likely use its $\mathrm{C}$ [omputer] $\mathrm{N}$ [etwork] $\mathrm{O}$ [perations] capabilities to attack select nodes on the [U.S.] military's Non-classified Internet Protocol Router Network (NIPRNET) and unclassified DOD and civilian contractor logistics networks in the continental U.S. (CONUS) and allied countries in the AsiaPacific region." The goal would be to "delay U.S. deployments and impact [the] combat effectiveness of troops already in theater." ${ }^{\prime 8}$ How effective such attacks would be cannot be ascertained with any degree of certainty. One needs to bear in mind that cyber threats "evolve (both on their own and as defenses against them are discovered), and new vulnerabilities often emerge as innovation changes underlying system architectures, implementation, or basic assumptions." ${ }^{\prime 49}$ The prospect of a cyber war with China is certainly unappealing to the U.S. government and military. The actual outcome of such a conflict is a matter of conjecture. But the point remains that the inherent uncertainty cannot deter the U.S. military from fulfilling its obligations under the TRA, an American law.

\section{WIDER CONSIDERATIONS}

One also needs to bear in mind that the actual capacity of U.S. forces to respond to a crisis across the Taiwan Strait a decade or two down the line will depend not only on the nature and scale of the Chinese threat at that time. It will also be affected by U.S. forces' current preoccupation with their missions in Afghanistan. All branches of the U.S. armed forces have come under great stress as a result

46. United States Government Accountability Office, Testimony before the Subcommittee on Strategic Forces, Committee on Armed Services, U.S. Senate (Statement of Cristina T. Chaplain), May 20, 2009 (Washington, D.C.: Government Accountability Office, 2009), p. I.

47. Russia did resort to cyber warfare against Georgia over South Ossetia in 2008, but it was not a contest between peers.

48. Krekel, Capability of the People's Republic of China to Conduct Cyber Warfare, p. 8.

49. National Research Council of the National Academies, Toward a Safer and More Secure Cyberspace (Washington, D.C.: National Academies Press, 2008), p. 35. 
of the extended deployment there- and in Iraq previously. This applies even to the Navy, which had I2,000 sailors "on the ground in U.S. Central Command's area of responsibility and 9,000 sailors at sea supporting combat operations" in early 2010.50 The high tempo of operations has also unquestionably led to much higher wear and tear on equipment and maintenance needs. The costs of deployment have also eroded budgeted funds that would otherwise have been spent on modernizing and upgrading existing capabilities. The imperative to ensure that U.S. forces are well supported for the current primarily counterinsurgency operations has meant that force development is being reoriented away from preparing for traditional conflict between states, to counterinsurgency and state-building purposes. The first signs of such a development can be seen, for example, in the capping of the number of F-22 Raptor air superiority fighters produced and deployed. This trend is also visible in the debates over whether the navy should focus on its littoral rather than blue water capabilities.

That said, current "high end" combat equipment and capital ships, and future "hybrid" war capabilities will synergistically provide the flexibility and scalability to meet major requirements of warfare across the spectrum. Likewise, while the risk of preparing for the last war cannot be avoided entirely, the current over-stretch of its forces does have a silver lining for the U.S. Senior officers in the next two decades will all have vast and real combat command experience, which is an intrinsic advantage that cannot be replaced by any amount of peacetime training.

The capacity of U.S. forces to deploy effectively in support of Taiwan's self-defense will also depend on the cooperation of some key U.S. allies. The greatest value of allied support is to confer legitimacy on any U.S. intervention. In military terms, the U.S. will not expect allies like the U.K., Australia, or NATO members to do more than provide warships to relieve the U.S. Navy from existing commitments so that it can deploy more of its own to the Taiwan area. But the navy will need Japan to make base facilities available and protect them..$^{51}$ If U.S. forces must give actual support to Taiwan, the

50. Lisa Daniel, “Tempo Takes Toll on Navy, Marine Equipment," America's Navy, February 26, 20IO, <http://www.navy.mil/search/display.asp?story_id=51559>, accessed March I, 2010.

5I. Although Japan has a significant missile defense capacity, the U.S. is unlikely to ask Japan to deploy its Arleigh Burke-class destroyers to strengthen the U.S. Navy's capacity because of concerns over Japan's constitutional constraints and the prospect that this would provoke the Chinese. For the security dilemma involved, see Thomas J. Christiansen, "China, the U.S.-Japan Alliance, and the Security Dilemma in East Asia," International Security 23:4 (1999), pp. 65-67. 
availability of the American air force base in Kadena and the Marine Corps base at Iwakuni (both in Okinawa) is of critical importance. If they can leave the security of such bases to their Japanese ally, this will significantly strengthen their capacity to deploy combat assets to the front. Whether any U.S. base on mainland Japan would be available would obviously be a matter of politics and diplomacy, and largely out of the hands of the U.S. military.

\section{POLICY IMPLICATIONS}

The most obvious conclusion is that however impressive the Chinese military modernization program may be in the next decade or two, the PLA can only substantially narrow the gap, not surpass the U.S., in military capabilities. On its current trajectory, China simply cannot build up sufficient advantage within such a time frame to deter the U.S. military from fulfilling its duty under the TRA. This will not change even if the PLA's progress were to exceed all expectations and U.S. force capabilities declined as a result of current deployments. The key issues here are attitude, assessment, and ethos, and the U.S. military would still feel duty bound to uphold an American law even at the cost of considerable losses.

The above does not imply, of course, that the U.S. government of the day will inevitably decide to help Taiwan defend itself. The specific conditions that give rise to such a contingency will have a massive effect on what policy makers in Washington do. The impact of the U.S. involvements in Afghanistan and Iraq may turn out to be greater on the political will of the nation than on the military's determination and capacity to take on such a challenge. A "post-Afghanistan syndrome" may emerge, similar to that which propelled American aversion to overseas military interventions after the Vietnam War. Or it may not. How the U.S. commitments in Afghanistan and Iraq will impact policy making cannot be known in advance. At the moment, the outcomes of these involvements are themselves undecided, and the timing of a crisis over Taiwan, should it come, cannot be predicted.

What this study shows is that Chinese military intimidation of Taiwan cannot deliver Beijing's preferred scenario as long as China cannot deter the U.S. from implementing the terms of the TRA. In a country built on the basis of the rule of law, a domestic legal commitment cannot be easily dismissed by any administration. The narrowing of the gap in military terms will no doubt make the U.S. military more cautious, but the ultimate decision to interfere 
or not is up to the political establishment of the day. The U.S. military will implement the order from the president following due process.

The democratic nature of politics in Taiwan also makes it practically politically impossible for any elected president of Taiwan to accept unification while Chinese deterrence against U.S. intervention remains ineffective. What China's threat to use force can achieve is to deter Taiwan from formally asserting de jure independence and changing its official name from the Republic of China to something like a Republic of Taiwan. Taiwan already acts on this deterrence.

Until the PLA can effectively deter the U.S. from helping Taiwan to defend itself, there is much to be said for allowing Taiwan to maintain a credible defense. As long as the U.S. requires none of its forces to become actively involved, it will continue to keep its military forwardly deployed and postured to respond. But U.S. forces are likely to be more forwardly deployed if the situation in the Taiwan region requires, which increases the risk of unintended escalation. Reducing such a risk matters if China's objective is limited to taking control of Taiwan by political and diplomatic means, and it has no wish to find itself unwittingly fighting a war with the U.S. whose outcome is unlikely to favor China in the foreseeable future. In other words, until Beijing can effectively deter the U.S. and thus coerce Taiwan to negotiate for unification, its best interest is served by reducing the risk for an unintended escalation.

For Taiwan itself, the most important implication is that it must maintain sufficient capabilities in case of an attack to hold out long enough for the American political process to run its course and for U.S. forces to be deployed to help. With the threat rising from China's expanding stock of short range ballistic missiles, Taiwan cannot hope to deploy sufficient anti-missile capabilities, which are disproportionately expensive. But it can prepare to strengthen its capacity to ensure that its command and control system and its major weapon systems survive the initial waves of missile attacks. Although Taiwan will need to modernize its defense systems, this should not be seen primarily in terms of major arms purchases.

The truly critical factors for Taiwan are securing the right kind of arms, building up the capacity to resist for several weeks with minimum American support, and upgrading its command, control, and communications systems so its military can communicate effectively with U.S. forces if the need arises. The reality is that a country of Taiwan's size cannot maintain a defense 
force large and well stocked enough to withstand the PLA on a sustained basis. Thus, for arms purchases a critical consideration is whether they can be quickly replenished by the U.S. from existing stocks. In this context, the F-I6 remains highly appropriate for the coming decade as long as Taiwan's air force pilots receive sufficient training. But this advantage will disappear as the bulk of F-I6s is retired from active U.S. service. Likewise, Taiwan can strengthen its capacity to hold out by investing heavily in non-lethal capacity (such as the resources to make temporary repairs to airfields) and in upgrading its communications equipment.

Given the stakes involved and the risk of escalation should the world's two leading nuclear powers find themselves in a military confrontation, the imperative must be for all parties concerned to find a way to deal with China's ambition without the use of force. Accommodation is necessary: the government in Taiwan cannot assert de jure independence, a clear red line for Beijing. ${ }^{52}$ But the key to a peaceful solution lies ultimately in the hands of the Chinese government. If it really wants unification with democratic Taiwan, it must make the prospect sufficiently attractive for Taiwanese voters. Until then, efforts should be made to deter Beijing from choosing the military option; this remains the best-case scenario in the foreseeable future.

52. The intricacies for the U.S. to deter both China and Taiwan from actions that could lead to a confrontation are laid out in Richard Bush, "The U.S. Policy of Dual Deterrence," in Tsang, ed., If China Attacks Taiwan, pp. 35-53. See also Nancy Bernkopf Tucker, "Strategic Ambiguity or Strategic Clarity?" in idem, ed., Dangerous Strait: The U.S.-Taiwan-China Crisis (New York: Columbia University Press, 2005), pp. I86-2II. 